Preliminary communication UDC 141.144:130.2

111.32:165.62

doi: $10.21464 / \mathrm{sp} 31102$

Received November $21^{\text {st }}, 2014$

Janez Juhant

University of Ljubljana, Faculty of Theology, Poljanska cesta 4, SI-1000 Ljubljana janez.juhant@guest.arnes.si

\title{
Authentic Human Nature and the World
}

\begin{abstract}
The issue of the relationship between person and nature is a modern one, but it has its roots in the problem of (genuine) Being (Sein), particularly the problem of the human being (Dasein), which is actually an anthropological question. Person as a being with logos governs herself as well as others and nature. As a symbolic being, she is confronted with the difficult task of finding a balance between herself and nature. The issue of this relationship escalated in the modern era because of society's exclusive concern with science and technology, which is primarily guided both politically and ideologically by a world ruled by media and technology. This world lacks the conditions for a genuine dialogue among persons. Yet logos itself has to maintain balance regarding its own true nature and this is possible only if a person is open to (all) other persons and dialogically open to solutions about the issues of the world in the context of a broader human nature. This type of responsibility is rooted in response. Responding includes hearing, and to hear means not only to listen to the voices of others, but also to hear their hearts and to feel them with one's entire being. This symbolic task is also deeply spiritual.
\end{abstract}

\section{Keywords}

nature, world, symbol, humans, person(s), dialogue, modernity, technique, ideology

\section{Introduction}

Persons as beings have a specific nature among all other beings in the world. They are beings who are endowed with reason (logon echon) and their corporeity is a window to the entire corporal (material) world (Damasio 2003). This presents a specifically human difficulty in the context of balancing between a person's own nature and the nature of other beings.

This paper presents the position of humans in the world as it was postulated by $\mathrm{M}$. Heidegger. Namely, his philosophy addresses the dilemma of human beings in the Western philosophic and cultural tradition and offers a sound basis to estimate the relationship between people and the world. The human being (Dasein) has a specific position among all other beings. Human being is Dasein; other beings are only vorhanden ('present-at-hand'). This specific position of human corporeal Dasein as a Geworfenheit ('to be placed', 'to be thrown', 'thrownness') in this world causes difficulties in regard to its relationship with the world. The Dasein has Sorge ('care'), meaning that human beings are beings of care. Besides this basic existentiell, two other existentiells endow human nature - language (Sprache) and speech (Rede), and understanding (Verstehen). Together, they make it possible for humans to deal with basic human dilemmas and to maintain balance between one's own life 
and the rest of the nature. Since early ages onward, a sound dialogue among diverse people, especially a dialogue among diverse people of different occupations, was a precondition for grasping the Dasein in its fullness.

To avoid usurpation of a relationship between person's own life and nature (the whole non-human world), people are required to continually search for their proper essence (Sein). Lack of dialogue is a cause of the externalisation (Entäusserung) of Dasein and of the compensation of being ("To Be") with having ("To Have") (Fromm 1976). The consequence is the development of an inhuman relationship toward oneself and towards other people. The disorder in the world originates in the disorder among people. In this paper, it is assumed that the lack of personal exchange (communication) between people results in the tendency of individuals to possess more than it is needed in the context of corporeal/material world, thus losing what they need in the context of spiritual world.

According to Judaist and Christian scripture, a person is the ruler of the world:

"Be fruitful and multiply, and fill the earth and subdue it; and have dominion over the fish and the sea and over the birds of the air and over every living thing that moves upon the earth." $($ Gen 1,28$)$

In this sense, we can suppose that a good dialogue among people is not only meant for a proper understanding of Dasein, and creating a ground for good relationships among people, but also for a proper way to rule the world, and subsequently a way of having successful relationships between people, and between people and all other living beings. People are able to pursue their specific human mission only through good interpersonal exchange. A person born in this world survives only through the other (mother or other persons), and so the survival of humans always depends on an authentic relationship among human beings, consequently influencing the relationship of human beings with other beings in this world (Damasio 2003, 4).

We will attempt to confirm the following hypothesis: good human interpersonal relationships fulfil people and ensure that they do not need to usurp other beings. They are fulfilled in their own nature, and therefore they do not need to compensate their being with having. Modern development of society rejected the guiding role of spirit (Mumford 1977) in human life, and allowed people to be guided by the so-called "objective world". The extreme form of this tendency is termed "instrumentalised reason". The biologist Jacques Monod described this as

“... rejection of centuries old spiritual tradition where spirituality is a decisive source of knowledge.” (Monod 1990, 281)

To realise one's life means to realise her spirit and her integrity. According to Christian tradition, this also includes a good relationship (dialogue) with God. God is an important presumption for the perfection of all human relationships, and for the establishment of human world order. Religiously speaking, the lack of a relationship with God implies the lack of interpersonal relationships among people. Dialogically able people can hear the otherness, and are able to respond to other's authentic human needs. Dialogically able persons are best equipped to solve the problems of the world. Today this is a global task, and a huge challenge for global humanity. The openness of human experience, which is present among all people, as well as among the so-called atheistic thinkers, fulfils this need for a deeper exchange among people. For the Ger- 
man philosopher Ernest Tugendhat (2003), the contingency, care for the $D a$ sein, and the dread of death (Heidegger) is the ground on which we are unable to find the living experience of the fulfilment of our life. So transcendence and the mystic grounding of all people make it possible

"... to become a new steadfastness of her/his life. The giving up the catchiness in the I - in the 'I want' and 'I want to possess' is in the different traditions of mystics experienced as setting free.” (Tugendhat 2003, 116-117; in Schlögl 2014, 131)

In opposition to this, bad interpersonal relationships do not stimulate humanity because they steadily awake a need to replace the interpersonal sources of humanity with the external materiality of the world; they stimulate the tendency of people to find their fulfilment in material things. The consequence of this deviation is the misuse of the world order and the disruption of the balance of life and its growth in this world. The ideological experiments of modernity were a culmination of this misdirection because they attempted to establish a world order on a totally impersonal, non-human and procedural power over people, and consequently, over the whole world.

\section{Person and Nature}

The problem of the relationship between a person and nature is a modern one. However, it originated in the Western philosophical tradition which can be considered, in a broader sense, the tradition of the whole civilisation. Through the Western Greek and medieval philosophical culture, a specific civilisation's project developed and further caused a rationalistic ordering of the world. This implies limiting the purposes of nature and usurping them for specific rational reasons.

"Intellectually speaking, modern science emerged through the complex interplay of Christian and Greek thought." (Pearcey, Thaxton 1994, 59)

In addition, the work of science in this tradition was always conditioned by suppositions grounded in religious backgrounds. This is the case in the approach of the modern world, established by "instrumental reason" and caused by the industrial-technical devices, which usurped the world in the Modern Age.

Martin Heidegger stressed that the Western philosophical culture originated from ancient Greek philosophers as a culture of being (Sein). Nevertheless, being was forgotten and philosophy was telling the story about being (Heidegger 1997, §2). Hence, it is necessary to grasp the structure of the Dasein, which means, according to Heidegger, to grasp the true Being, the Sein $(1967,27)$. Dasein ('Being here', meaning 'the human existence') possesses the real being as opposed to the other things (beings) that are only here, present-at-hand (vorhanden). According to Heidegger, only a human being as a special being in the world is burdened with the care (Sorge) for the Dasein and she is different from other things (beings) that are without such care. This fundamental state of a human person is the potentiality for dread (Angst) as one's "Being-in-time" (Heidegger 1967, 44), and the caring for herself. The dread as a ground causes the care.

"The constitution of 'Verfallen' ['thrown', "the Dasein is entirely concerned and occupied with the 'world' of its care"] as a mode of 'in Being' is not anything that speaks against the existentiality of Dasein, on the contrary, it is a weighty proof for it. For throughout the whole process of 'Verfallen', Dasein is concerned about nothing else than its own potentiality of 'Being-in-theworld'.” (Heidegger 1967, 43) 
This "structural whole" is the cause of the "fall" and designates the Dasein with the care. To avoid this care, a being tends to worldliness of the world and to Being-together-with-others.

In the following discussion, firstly, we will show that this "Being-togetherwith-others" is constituted by speech (Rede). As a person's basic dialogical existentiell, it opens the real human powers to avoid the one-sided decisions of a person for herself, and for the world, because one-sided decisions cause the delusions of creation. The language (speech) is the most important of the three existentiells, beside Geworfenheit ('to be placed') and Verstehen (understanding) (Heidegger 1967 34-40). In the ontological turn, the main characteristics of persons are as follows: Geworfenheit (to be placed), which means that a person is placed in this world and has to manage her own situation; Sprache (Rede), as a person's device to deal with this situation. Speech and understanding make it possible to face the Geworfenheit (thrownness) of Dasein. The philosophy of the New Ages cultivates more individualistic possessive speech, which departed from the tracks of Dasein. The stressing of the world's dimension of people leads to a one-sided picture of a person and the world, which can be summarised as a worldliness of human being and its loss in the world of things.

Secondly, we attempted to show that the tendency to worldliness, as a consequence of the care, was, and still is, a steady temptation of Dasein to cover its care with turning towards the things of the world. The instrumental reason has been externalised to fit this Dasein's care. The development of the achievements of science and techniques in the modern world, as a consequence of the Western scientific tradition, the emphasis on the role of the human being in the world, and the socio-political concentration of this role in some individualistic or collective (imperialistic and dictator's tendencies) have led to people's expansion over other beings and over the rest of the world. To come to the authentic relationship between a person and the world, we must first discuss the corporeity of people in the context of being in contact with other (material) things.

\section{Body dilemmas and materiality}

In her book Plato and Levinas, Tanja Staehler presents the importance of the human body in all human relationships (Staehler 2010, 54). Plato, Levinas, and other thinkers (such as Husserl and Merleau-Ponty) agreed that the body is an important dimension of the human interior, "which is involved in enjoyment and suffering". To express this, people use their own body and other corporeal beings.

Firstly, the human body is unique. It is different from any other thing because our body opens us towards the world. Plato stressed that the body could not be ignored, which was against the common understanding that Plato treated the body within disdain, stressing only the spiritual dimension of human beings. According to Levinas (and Plato), the body "opens us up to the world as well as to logos". Secondly, the body is an organ which makes the "exchange and even reversibility between one and the world" possible. This is very important for "any subject-object relationship".

"Thirdly, Levinas moves on from previous accounts of corporeality to stress that sensibility is intimately connected to vulnerability, thus adding an ethical dimension." (Staehler 2010, 55)

This claim is supported by Antonio Damasio in the sense that, through their corporeity, people express their emotions (Damasio 2003). 
In summary, according to Staehler, three aspects of corporeity can be seen in Plato and Levinas. Firstly, the body differs from other material things, because the body cannot be separated from the soul. The body opens us to the world and logos. It is a living materiality. Secondly, because of the body, there is a permanent exchange between us and the world (subject-object relationship). Thirdly, according to Levinas, sensibility as a corporeal characteristic also means vulnerability. This dimension causes troubles in relationships among people and in their relation to the material world; it makes us receptive of other beings. The body is passive (receptive) to all other things and beings, and so it is under their influence. They affect it, and consequently, they leave their mark on it. A person as a corporeal being is constantly under influences, which make her receptive towards all the currents of the environment. In this sense, relatively speaking according to social theorists, a person is a product of the environment. However, a passive influence is not the only thing present; there is also a continuous exchange between a person and her milieu, and an active relation between the person and the world. This often causes difficulties in the world.

Because of this interconnectedness, there are troubles among people who are concerned with the limits of corporeal things and the unlimited desire of people seeking these things. The decisive point is the relationship among people concerning their relationships to things. The problem is not primarily between people and things, but among people in their desire for things they want to possess. The desire for things is a source of permanent quarrels among people and consequently the source of problems regarding the order in the world. People are the decisive factor in ruling the world and in regulating the beings of this world. This issue escalated noticeably in the latest centuries of human history.

There are no a priori rules regulating how one can access another with respect to material things and this openness is the constant source of attacks and/or subjugations of self or the other. Because of the relational complications rooted in the corporeal structure of human beings, the community has difficulties in arranging these processes, developing the rules or the symbolic forms, prohibitions and laws, to avoid violence arising from these relationships and processes. This is the cause of regulation by rites and ceremonies, which exists to protect the community from violence. According to René Girard (1987), the humanisation of these complex tensions among individuals and communities is either mythically or religiously founded. In the Modern Age, the religiously founded rules lost their influence over individual and societal life. Consequently, because of the constant presence of the corporeal dimension in all deeds and processes of human life, the order of the world has become problematic. This causes struggles in the battle of survival and it is a source of violent tensions among individuals and groups.

On the other hand, the important consequence of this materiality (corporeity) of all beings in the world is their availability to others, the possibility of giving life for the other or to take the life from another person so that one could survive. All life in the world is maintained by the lives of others. In some sense, others are victims so that we can survive. The modern ideologies were inclined to ignore the lives of others and victimize the others for purposes of the idealistic wholeness: class, nation or other ideological entity. The liberal ideology and its followers in different systems, such as Nazism, fascism, and communism were ready, in the name of "progress", to victimize people, and to offer their lives for ideological purposes. This pulled people, and the whole 
world, into an ideological totalitarianism, and it polluted nature without respecting the victims of this "progressive" development. The necessary equilibrium (balance) of the life of the world, and the development of the whole planetary world were dangerously threatened. We speak from the perspective of instrumentalist reason, which usurped total command over the world without dialogue with their entities, especially with people.

\section{Instrumentalist reason - the "world" as a total system}

People restrain from doing anything that has not been accepted into their symbolic capacity, which is culturally grounded. In this sense, they are interpreting the whole world in symbolic terms, and science is also one such product. Therefore, the world is mysterious and mystical, and no one has the last word about it. Together we are all searching for it. Wittgenstein said:

"It is not how things are in the world that is mystical, but that it exists." (Wittgenstein 2001, 6.44)

Therefore, the claim that "man is a machine" (de La Mettrie, in Pearcey, Thaxton 1994, 95) is just as mystical as any other claim regarding the Dasein (existence). In this sense, a person needs to deal with this mystical fact of her own thrownness (Geworfenheit) in this world. Pearcey and Thaxton (1994) convinced us that even scientific knowledge is involved in a distinct faith about our world. It was a mistake to use scientific, but especially political and ideological views to usurp scientific knowledge, and to fill it with their totalitarian ideological standpoints without respecting the principal position of $D a$ sein in this world. In order to deal with the problem, language (Sprache) and understanding (Verstehen) were excluded. However, we are unable to confirm any of these standpoints without proving them dialogically, that is without founding the proof on the basis of a correct dialogue among (different) partners, including scientists, in a sense of responsibility towards each other and towards the beings of this world. Bertrand Russell claimed:

"Philosophy should show us the hierarchy of our instinctive beliefs, beginning with those we hold most strongly, and presenting each as much isolated and as free from irrelevant additions as possible. It should take care to show that, in the form in which they are finally set forth, our instinctive beliefs do not clash, but form a harmonious system. There can never be any reason for rejecting one instinctive belief except that it clashes with others; thus, if they are found to harmonize, the whole system becomes worthy of acceptance." (Russell 1980, 12)

Our world views are open for the processes of dialogic proof.

"The need for accountability to our experience also reveals another important epistemological overlap between theological and scientific modes of inquiry. Because we relate to our world epistemically only through the mediation of interpreted experience, it may be said that our diverse theologies, and also the sciences, offer alternative interpretations of our experience (Rolston 1987:1-8). Alternative, however, not in the sense of competing or conflicting interpretations, but of complementary interpretations of the manifold dimensions of our experience." (Huyssteen 2006, 15)

People can only correct the errors of their experiences by openness to dialogue. Meanwhile, the modern world presents us with an unsolved problem; consequently, the language system plays a much more important role. Many thinkers of the $20^{\text {th }}$ century contemplated the problem of the modern scientific culture. For example, Jürgen Habermas and Karl-Otto Apel criticized the totalitarianism of the political, economic, and technical systems, and the rise 
of instrumentalist reason (see Vattimo 2004, 83). The problem culminated in the development of the philosophy and sciences of the Modern Age. To balance all of our experience, we need a dialogue of the different symbolic structures of our experiences. Modern thinking was declared objective and neutral, not subjective. But the truth is the opposite, as Žalec points out, quoting Nietzsche, who saw that

“... what was shown as an objective was in fact a subjective will." (Žalec 2005, 128; Strahovnik 2009, 252-254)

Science and other human-organised activities are therefore only a part of the framework of people's symbolic world, and they deal with the same practical question: how can people organize their lives better? The answer depends on our common valuations, hopes, and strivings. Science is an (important) part of these organisations, especially in the modern world, but it should always be regarded only as one part of the symbolic structure of people's world. It is very important to involve it in a global dialogue with all other parts of our existential experiences, which brings up the question of integral symbolic dialogue. In the globalized world we cannot act without taking into consideration religious and ethical backgrounds. They are a constitutive part of our symbolic world. To exclude their reality would result in the misuse of science for ideological purposes, as was the case with the modern "instrumentalist reason". Philosophers should be critical regarding this ideology of language, which makes people "dependent on the culture of today's machines" (Mumford 1977, 52). Hence, they are often a product of the world of celebrity (Virilio 2006) and media (McLuhan 1964). Its language is closed, and it is understandable that modern sociology searches for an open society (Popper 1945).

In this sense, people's position is always mystical and Dasein's care is a special product of the modern thrownness (Geworfenheit) of person. According to Mumford, the human language is an open and mysterious project of people and it can run towards an objective or a more subjective world (Mumford 1977, 91). Therefore, there is always the danger of a one-sided lingual solution. As Heidegger pointed out, understanding (Verstehen) the human position in the world could be managed by a dialogical society. In the Western world, and more and more in the whole world as such, only the objective side was stressed, and real Dasein forgotten. We speak more about the material side of our being. In other words, we speak more about things than about ourselves. The "myth of the machine" is an attack on human spirit as a ruler of life.

\section{Person as a complex being}

Because person is a symbolic, complex, and ungraspable being, her genesis is full of misdirection and stagnation, but also includes possibilities for new ways, hopes, and challenges. Mumford named it the human drama (Mumford, 1977, 810). According to him, there was always the problem of letting human life be guided under the creativity of the spirit. All historical and cultural acquisitions were the result of the spirit. Humans tried to symbolically organize and fulfil their being and to include in it all beings and things of this world. The symbolic function is guided, or at least it mostly should be, by the spirit towards summing up all human desires, plans, symbols, phantasies, and the other content of the human spirit. The human spirit is the centrum of all these happenings belonging to the human being. Even all the technical and 
other devices of the human world are included in these processes (Mumford, 1977, 817). All subjective and objective occurrences are complementarily supplemented. The decisive move is communicating in order to put all this events into interpersonal exchange.

When humans communicate, the core of every person is steadily renewed and refreshed. In the opposite case, it is altered by the outer non-human events and things. The modern development is stimulated by the latter. The question arises as to how we can deepen interpersonal processes and encourage individuals to communicate, which is today a necessary local and global process, and which would result in cooperation on the global scale.

\section{Dialogue as an affirmation of spirit and human order}

Throughout her marriage, British princess Diana was immersed in a very difficult and dangerous life work. It was impossible to survive and to find balance in life. She was determined to turn her life to the poorest and those excluded from society such as the ill and dying children: the kind of people who were cared for by Mother Teresa. In this way she became the princess of human hearts. It was not only her personal psychological training, but also her professional and humanistic experience that contributed to her realisation of humanity.

Lev Vygotsky stressed the importance of communication for the development of human language. Dialogue at an early age stimulates openness to the physiological conditions which facilitate the development of the individual's language. Lewis Mumford illustrated the same case from the perspective of the development of modern civilisation: modern electronic "one-way communication" buries dialogue and the possibilities of a multilateral world (Mumford 1977, 118-119). Dialogue allows consideration and cultivation of humanity. The lingual/spoken world can open different people's worlds, and allows access to their plurality in order to transcend and avoid one-sided manipulations or alienations of human language.

There are many signs that the course of this world has been altered and is still to be altered. The language of the world has been changed. We need to deal with the dangerous tempo of our development and we have no means to slow it down. Likewise, we need to deal with many senseless habits and practices that pervert traditional habits and values. The words of the Chinese philosopher Confucius (551-479 BC) are spot on, as Mumford points out:

"... he made use of two appointed means to establish again in his time the social order on a sound basis. The first one was re-establishing the old rituals, the second one was to clarify the language." (Mumford 1977, 109)

Munford states that words such as

“... intellectual confusion, crime, perversion, taking of dignity (soiling), torture and unselective murdering are in the language of many contemporaries viewed as 'good'; meanwhile, rational thinking, bridling, personal honesty and kindly friendship are considered to be 'bad' and worthy of hate." (ibid.)

This is only one side of the language perturbation. The other side shows that the human substance was reduced or limited only to the material, productive or gainful aspect. Mumford stressed the technical side of language as an important organisational means for people to survive in this world. Psychologists Lev Vygotsky and Antonio Damasio put more emphasis on the 
emotional component. This is not only a technical problem, but much more a humane problem regarding the mutual exchange within humanity.

\section{Conclusion}

The human position marked by Geworfenheit could not be analytically discovered. Thus, the human position is a mystical one. We can gain access to it only by understanding and employing language as a dialogical symbolic process. The rites and languages (Mumford) make possible for a symbolic structure of the world. This can be accomplished through dialogue as a way toward an authentic picture of the human position and consequently toward an open and adequate humanistic worldview. The temptations of modernity, the scientific-technical, ideological, closed picture of the human being and the world, accompanied by the misdirection of modern scientific-technological and socio-political development, open serious problems regarding the human position in the world today. They can be solved only by mindful work and sincere dialogue among people. Human Geworfenheit can be dealt with by such a dialogue in which understanding and language will contribute towards a mutual exchange regarding human caring. Only in this way can the balance be maintained between selfish people's temptations to usurp the whole world and the openness of people to include the whole world. Authentic human dialogue is not only a global necessity but also a steady acknowledgment and confirmation of authentic human sources which are ultimately the best way to restrict the human occupation of the world.

\section{References}

Damasio, Antonio (2003). Looking for Spinoza: Joy, Sorrow and the Feeling Brain. New York: Harcourt.

Fromm, Eric (1976). To Have or To Be?. New York: Harper \& Row.

Girard, René (1987). Things Hidden from the Beginning of the World. Stanford: Stanford University Press.

van Huyssteen, J. Wentzel (2006). Alone in the World? Human Uniqueness in Science and Theology. Göttingen: Vandenhoeck \& Ruprecht.

Heidegger, Martin (1967). Existence and Being. Chicago: Gateway Edition.

McLuhan, Marshall (1964). Understanding Media. Extensions of Man. New York: Signet Books.

Monod, Jacques (1990). "Zufall und Notwendigkeit. Philosophische Fragen der modernen Biologie". In: Oelmüller, Willi; Dölle-Oelmüller, Ruth; Geyer, Carl-Friedrich (eds.). Philosophische Arbeitsbücher 7. Diskurs Mensch. Paderborn: Schöningh UTB, pp. 272-281.

Mumford, Lewis (1977). Der Mythos der Maschine. Kultur, Technik und Macht. Fischer: Frankfurt.

Mutschler, Hans-Dieter (2014). "Die Dogmen des Naturalismus”. In: Theologie und Philosophie 89, pp. 161-176.

Pearcey, Nancy R., Thaxton, Charles B.(1994). The Soul of Science. Christian Faith and Natural Philosophy. Wheaton (IL): Crossway Books. doi: http://dx.doi.org/10.2307/3170570.

Popper, Karl (1945). The Open Society and Its Enemies. London: Routledge \& K. Paul.

Rolston, Holmes (1987). Science and Religion: A Critical Survey. New York: Random House.

Russell, Bertrand (1980). The Problems of Philosophy. Oxford: University Press. 
Schlögl, Manuel (2014). "Mystik als Freiheitsgeschehen. Die anthropologische Begründung der Mystik bei Ernst Tugendhat und Joseph Ratzinger". In: Theologie und Glaube 104 $(2 / 2014)$.

Staehler, Tanja (2010). Plato and Levinas: the Ambiguous Out-Side of Ethics. London: Routledge.

Strahovnik, Vojko (2009). Moralne sodbe, intuicije in moralna načela [Moral Judgments, Intuitions and Moral Principles]. Velenje: Inštitut za simbolno analizo in razvoj informacijskih tehnologij.

Tugendhat, Ernst (2003). Egozentrizität and Mystik. Eine anthropologische Studie. München: C. H. Beck Verlag.

Virilio, Paul (2006). Speed and Politics. An Essay on Dromology. New York: Semiotext(e).

Wittgenstein, Ludwig (2001). Tractatus Logico-Philosophicus. London - New York: Routledge.

Žalec, Bojan (2005). Doseganje dobrega [Reaching of Good]. Ljubljana: Claritas.

\title{
Janez Juhant
}

\section{Autentična ljudska priroda i svijet}

\section{Sažetak}

Pitanje odnosa između osobe i prirode je modernoga porijekla, no ima svoje korijene u problemu (autentičnog) bitka (Sein), naročito ljudskog bitka (Dasein), što je ustvari jedno antropološko pitanje. Osoba kao biće s logosom vlada sobom kao i drugima te prirodom. Kao simboličko biće osoba je suočena s teškim zadatkom pronalaska ravnoteže između nje i prirode. Ovo pitanje veze eskaliralo je u modernome dobu zbog isključive brige društva za znanost i tehniku, politički i ideološki vođenu prvenstveno kroz medijsko-tehnološki ovladan svijet, pri čemu nedostaju uvjeti za autentičan dijalog između osoba. No logos sâm mora održavati ravnotežu s obzirom na njegovu pravu prirodu a to je moguće jedino ako je osoba otvorena prema (svim) drugim osobama te dijaloški otvorena rješenjima svjetskih problema u kontekstu šire ljudske prirode. Ovaj tip odgovornosti ukorijenjen je u odgovoru: odgovaranje uključuje slušanje, a čuti znači ne samo slušati glasove drugih, nego i čuti njihova srca te osjetiti ih u punini vlastitoga bića. Ova simbolička zadaća duboko je duhovna.
\end{abstract}

\section{Ključne riječi}

priroda, svijet, simbol, ljudi, osoba/e, dijalog, modernost, tehnika, ideologija

\section{Janez Juhant}

\section{Die authentische menschliche Natur und die Welt}

\section{Zusammenfassung}

Die Frage der Beziehung zwischen einer Person und der Natur ist eine zeitgenössische Frage, jedoch schlägt sie ihre Wurzeln im Problem des ((eigentlichen) Seins), insbesondere des Menschen (Dasein), was eigentlich eine anthropologische Frage ist. Eine Person als ein Wesen mit Logos regiert sich selbst ebenso wie die anderen und die Natur. Als ein symbolisches Wesen ist sie mit der diffizilen Aufgabe konfrontiert, ein Gleichgewicht zwischen sich selbst und der Natur zu finden. Dieses Beziehungsproblem eskalierte in der modernen Ära infolge des exklusiven Interesses der Gesellschaft an der Wissenschaft und Technologie, die politisch und ideologisch in erster Linie von einer medientechnologisch geregelten Welt gelenkt werden, wobei es an Voraussetzungen für einen echten Dialog zwischen den Personen mangelt. Jedoch muss der Logos selbst in Bezug auf dessen eigene wahre Natur das Gleichgewicht aufrechterhalten und dies ist nur möglich, wenn eine Person für (alle) andere(n) Personen und dialogisch für Lösungen der Weltprobleme in einem breiteren Kontext der menschlichen Natur offen ist. Diese Art von Verantwortung ist in einer Antwort verwurzelt: Eine Beantwortung umfasst das Zuhören, und zuhören heißt nicht nur, 
auf die Stimmen der anderen zu hören, sondern auch auf deren Herzen zu hören und sie mit dem ganzen eigenen Wesen zu fühlen. Diese symbolische Aufgabe ist zutiefst spirituell.

\section{Schlüsselwörter}

Natur, Welt, Symbol, Menschen, Person(en), Dialog, Modernität, Technologie, Ideologie

\section{Janez Juhant}

\section{La nature humaine authentique et le monde}

\section{Résumé}

Bien qu'elle ait ses racines dans le problème de l'(authentique) Être (Sein) et plus précisément dans celui de l'être humain (Dasein), la question de la relation entre la personne et la nature est un problème contemporain qui, à vrai dire, relève de l'anthropologie. En effet, une personne en tant qu'être doué de logos qui se gouverne, se gouverne aussi bien elle-même que les autres et la nature. En tant qu'être symbolique, la personne est confrontée à la difficile tâche de trouver un équilibre entre elle et la nature. Le problème de cette relation s'est intensifié dans l'ère moderne en raison de l'intérêt exclusif accordé par la société à la science et à la technologie, guidées toutes deux par une politique et une idéologie appartenant à un monde dirigé par une technologie médiatique qui néglige les conditions favorables pour un dialogue authentique entre les personnes. Or le logos lui-même doit maintenir cet équilibre en regard de sa véritable nature et cela est possible uniquement dans la mesure où la personne est ouverte aux autres personnes (dans leur totalité) et au dialogue, afin de trouver des solutions aux problèmes du monde dans un contexte plus large de nature humaine. Ce genre de responsabilité s'enracine dans une réponse : le répondre inclut l'écouter ; écouter ne signifie pas seulement entendre la voix des autres, mais aussi leur cour en les ressentant dans la totalité de leur être. Cette tâche symbolique est profondément spirituelle.

\section{Mots-clés}

nature, monde, symbole, humains, personne(s), dialogue, modernité, technologie, idéologie 